\title{
Exposure as Collected Portion or Totality
}

National Cancer Institute

\section{Source}

National Cancer Institute. Exposure as Collected Portion or Totality. NCI Thesaurus.

Code C117491.

A qualifier for the arrangement or apportioning of an entity within a body part, region or organ for the collected exposure assessment. 